\title{
John Gillingham
}

\section{Jean Monnet and the New Europe}

What did Jean Monnet contribute to the creation of the New Europe? That is a simple, though much studied, question. Two important Monnet biographies have appeared in the past few years, one a thousand page, hexagonal work by Eric Roussel, the other an elegant insider's account by François Duchêne ${ }^{1}$. The volume of papers, articles, and monographs about the formidable Frenchman also continues to expand impressively, and successive colloquia occur in apparently unending procession. A recent one, which took place in 1997 in Paris, produced over twenty scholarly papers about episodes in his career ${ }^{2}$. They shed new light on Jean Monnet's role in reconciling Germany and France after 1945 and illuminate certain of the changes thanks to which the post-World War II settlement did not merely repeat the disastrous mistakes of the previous one. In examining this central issue, the present essay aims to contribute something to an overall assessment of the man's life and work.

The current trend in Monnet literature is hardly revisionist, indeed at times approaches the hagiographic. The Monnet that emerges from it is a person of immense determination and force of character; a visionary; a mover of men, ideas, and institutions; someone possessed of vast experience, considerable expertise in how to get things done, great gifts as an inside operator, and an extraordinary power to persuade the movers and shakers of his age to act on his behalf. To his most ardent devotees he is, quite simply, l'Inspirateur.

To understand the nature and scope of Monnet's influence, one must know something about his long and distinguished career as a public figure ${ }^{3}$. It began in August 1914 at age twenty-six, when the determined young man, after having with the help of an influential friend arranged an audience with the Prime Minister of France, predicted to the astonished elder statesman that economics, not battlefield heroics, would determine the outcome of the war. The following day Monnet received orders to set up a joint purchasing mission with the British. That organ-

1 Eric Roussel, Jean Monnet, 1888-1979 (Paris 1996); Fraņ̧ois Duchêne, Jean Monnet: The First Statesman of Interdependence (London 1994).

2 Jean Monnet, l'Europe et les chemins de la paix, Paris 29-31 mai 1997 (organisé par l'Institut Pierre Renouvin de l'Université de Paris I, L'Institut Historique Allemand et La Fondation Jean Monnet pour l'Europe, Lausanne).

3 Jean Monnet, Memoirs (London 1978). 
ization eventually enabled the allies to monopolize world shipping and provision their armies from overseas. Monnet's engagement in public affairs ceased shortly before his death in 1979 at age ninety, by which time he had been proclaimed by the European Council the first (and is still the only) Honorary Citizen of Europe.

Between those two dates Monnet acquired a depth and variety of experience that few men of his generation could equal. To touch on only a few salient points in his career, Monnet served as deputy to the Secretary General of the League of Nations in the early 1920's and, later in the decade, as head of European operations for Blair \& Co., a Wall Street bond underwriter. During the Depression he tried and failed to take over the Bank of America, liquidated the fallen KruegerToll match empire, and launched an ambitious but disastrous project for an Asian development bank with partners from the Kuomintang.

The year 1938 proved a turning point in Monnet's life ${ }^{4}$. Instead of rebuilding his ruined finances, he launched a successful one-man campaign to persuade the French government to begin massive purchasing of American aircraft for the war he expected to break out in the near future, and in the following year crossed the Atlantic to handle order placement ${ }^{5}$. After the Fall of France, instead of joining General de Gaulle in London, he secured an appointment as second-in-command of the British Lend-Lease committee in Washington. In 1943 he became trade minister in the French Provisional Government in Algiers 6 . In 1946 Monnet was named Commissaire of the Plan de Modernisation et d'Equipement - the so-called Monnet Plan ${ }^{7}$. Four years later he masterminded the Schuman Plan, directed the negotiations that led to the creation of the European Coal and Steel Community, and eventually served as President of its High Authority ${ }^{8}$. Monnet also authored the Pleven Plan for a European Defense Community and was the prime mover of the EURATOM proposal incorporated into the Treaty of Rome creating the European Economic Community. Finally, the by-then famous senior statesman inspired President Kennedy's Grand Design as well as the Multilateral Force proposal upon which it rested. Monnet continued to work tirelessly in Bonn, London, and Paris as éminence grise for Europe until well into the final decade of his life?.

Monnet stands as a protean figure, but his greatest achievements belong to the formative years after 1945. It was then that the tradition of economic planning took hold in France, then too that Europe's "first supranational institution" arose from the Schuman Plan as a vehicle of Franco-German reconciliation and a prime mover of integration diplomacy. It was then finally that, thanks in no small way to

4 Duchêne, op.cit., 61.

${ }^{5} \mathrm{John} \mathrm{McV.} \mathrm{Haight,} \mathrm{American} \mathrm{Aid} \mathrm{to} \mathrm{France} \mathrm{(New} \mathrm{York} \mathrm{1970).}$

6 André Kaspi, La Mission de Jean Monnet à Alger mars-octobre 1943 (Paris 1971).

7 Michel Margairaz, La Mise en oeuvre du Plan Monnet, in: $B$. Cazes and $P b$. Mioche, Modernisation ou décadence? (U. de Province 1990).

${ }^{8}$ John Gillingham, Coal, Steel, and the Rebirth of Europe: The Germans and French from Economic Conflict to European Community (Cambridge 1991).

${ }^{9}$ Richard Mayne, Jean Monnet: Eminence Grise for Europe (unpublished manuscript, 1975). 
his efforts, the Atlantic Alliance - indispensable prerequisite for the new diplomatic era in Western Europe - solidified. One cannot say that without Monnet the French and Germans would not have reconciled, nor that integration would never have taken place, nor even that a military pact between the United States and the West European nations might not have developed into an ocean-spanning community. Yet it is hard to imagine how those things would otherwise have happened. It is well worth asking why Monnet succeeded where others did not.

The answer is not obvious. Monnet built no important institutions, with the exception of the French Plan, and even it developed other than as he had foreseen. General de Gaulle correctly described the abortive Multinational Force proposal as a multinational farce. EURATOM got off the drafting board, but proved a nonstarter ${ }^{10}$. The European Defense Community was a bad idea - anti-parliamentary, a source of diplomatic conflict, and an unwelcome and costly distraction from the real world - though for a Federal Republic eager for respectability it served as a useful smokescreen ${ }^{11}$. The European Coal and Steel Community, while a diplomatic triumph, was economically dysfunctional and quite properly disregarded as a model in the negotiations that led to the formation of the European Economic Community in $1958^{12}$.

Nor did Monnet found a party, movement, or school. Although insightful, able to draw on his wealth of experience, and open to new ideas, he was less an original thinker than an "original doer". His special method was to work outside of governmental structures, bureaucracies, and official channels, while always remaining close to centers of decision-making. His greatest gift was an uncanny ability to persuade powerful men to champion what he stood for. Yet Monnet could "inspire" only when the situation permitted.

The key to Monnet's influence in postwar Europe was the American connection, as for example with the French Plan. Proposals for something like a Plan de Modernisation et d'Equipement featured prominently in the preparations for reconstruction and development undertaken under the auspices of both the Vichy and London governments, as well as in the programs of the Resistance ${ }^{13}$. Pierre Mendès France and Georges Boris, the two previous commissaires, were technically better qualified than Monnet to direct such an organization. His ace in the hole was access to dollars: he managed to have nearly half of France's Marshall Plan aid earmarked for Plan investment projects that, given the fierce competition for scarce resources, the French Chambre would never have funded ${ }^{14}$.

10 Antonio Varsori, Euratom, une organisation qui échappe à Jean Monnet (unpublished manuscript from "Jean Monnet, l'Europe et les chemins de la paix").

${ }^{11}$ John Gillingham, American Monnetism and the European Coal-Steel Community in the Fifties, in: Journal of Integration History I (1/1955) 26.

12 Gillingham, Coal, Steel, op.cit, 299-363 (Ch.6: The Success of a Failure).

13 Ibid. 73; Richard F. Kuisel, Capitalism and the State in Modern France (Cambridge 1983).

14 Irwin M. Wall, The American Marshall Plan Mission in France, in: René Girault and Maurice Lévy-Leboyer (eds.), Le Plan Marshall et le relèvement économique de l'Europe (Paris 1993) 133-143. 
The American connection was also Monnet's main source of strength in the Schuman Plan negotiations. Proposals for a West European heavy-industry pool had been commonplace in economic diplomacy since the 1920s and were a staple item in the postwar planning not only of France but of the other European nations and the United States as well ${ }^{15}$. The familiarity of such coal-steel proposals accounts in part for the enthusiastic reception given the Schuman Plan announcement. Yet the French feared Germany, and the Germans demanded equal treatment with the French. American support enabled Monnet to square the circle and conclude negotiations for the European Coal and Steel Community successfully.

Monnet's power waned as Europe recovered and America's importance declined. The European Defense Community, EURATOM, and the Multilateral Force all failed. Monnet was moreover never as influential in Bonn or London as in Washington, and in Paris he often had trouble even getting a hearing. But if all doors in Europe had in fact been open to him at some point, his greatest impact would still have been in the recovery period. Seldom have so few hands held so much power as in Washington after 1945. In his later role as "Senior Statesman for Europe", Monnet was, to be sure, hardly a spent force: from the late 1950s to the 1970 s he was a fount of new ideas for tying together the nations of the continent. He had a major influence on, among others, Edward Heath, Helmut Schmidt, and Valéry Giscard d'Estaing, and he continued to attract new disciples eager to apply his "lessons" to policy. After the mid-1950s, however, he no longer had a hand in making the big decisions.

Monnet learned how to refashion Europe in wartime Washington ${ }^{16}$. Arriving as British Lend-Lease representative after the Fall of France, during the period of American neutrality, he witnessed a mobilization conducted on a scale not merely previously unknown but believed to be impossible, watched carefully as a cagey but far-sighted president maneuvered a wary nation into war, and discovered the sometimes strange way that power and influence trade hands on the banks of the Potomac. There, too, he made or strengthened friendships indispensable to his later achievement - with Dean Acheson, John Foster Dulles, Averell Harriman, and David Bruce, to mention only a few recognizable names ${ }^{17}$. Like him, these men were "all outers" intent upon maximum political and economic mobilization for a war thought to be unavoidable.

In Washington only Bernard Baruch, whom Roosevelt deliberately kept at arms's length, could match Monnet's expertise in the arcane science of Kriegsmanagement. The Frenchman had, or at least seems to have had, convincing answers to most of the weighty economic questions confronting the nation. As a "resister of the first hour", he occupied high moral ground. And he was accustomed to

15 Gillingham, Coal, Steel, op.cit., 28-45, 52-65; Dirk Spierenburg and Raymond Poidevin, The History of the High Authority of the European Coal and Steel Community (London 1994) 1-5.

16 Jobn Gillingham, Jean Monnet and the American Victory Program (unpublished manuscript from "Jean Monnet, l'Europe et les chemins de la paix").

17 Ibid. 
doing business the American way, informally, with few words, and often late into the night. Monnet came to be the European the White House most trusted and relied upon. He was therefore the logical choice to serve as Washington's man in the French Provisional Government and to undertake, unofficially to be sure, the task of reining in General de Gaulle. His means to that end was the American aid pipeline which, as chief of supply for the Free French in Algiers, he controlled ${ }^{18}$.

The basic postwar relationship between France and the United States resulted from Monnet's renegotiation of the bilateral Lend-Lease agreements in 1945: the US prolonged aid deliveries, and France agreed to liberalize trade and make the currency convertible. The French, in short, would modernize so long as the Americans subsidized the effort ${ }^{19}$. With this bargain in mind, and in one of his final acts before resigning in February 1946, General de Gaulle thus issued an executive order creating the Plan de Modernisation et d'Equipement and named Monnet its Commissaire. In negotiating the Byrnes-Blum loan of May 1946, Monnet secured special consideration for the Plan's investment projects, and over heated protests from both the Chambre and the Treasury spent over half of it on them ${ }^{20}$.

The opposition encountered by the Plan is hardly surprising: its various industrial investments would have absorbed a quarter of the national budget, were it not for American aid, which covered 51 percent of Plan outlays in 1947. The amounts increased under the Marshall Plan to 53 percent in 1948 and 72 percent in 1949 before declining to 53 percent in 1950 and 16 percent the following year, by which time the increased availability of aid under the Medium Term Defense Plan offset the reduction in Marshall Plan assistance ${ }^{21}$. As Jean-Pierre Rioux quite properly emphasizes in his excellent survey of the Fourth Republic, American aid money enabled the French state to direct the reconstruction process ${ }^{22}$.

It may well be, in light of the Malthusianism that pervaded French business, that Monnet's approach to recovery was the only one feasible. It did, however, have a downside: it was inflationary, misallocated resources, and created statist attitudes that eventually impeded growth. Whatever its drawbacks, American aid administrators nevertheless considered the French model exemplary. Much New Deal-like thinking went into the Monnet Plan. Its high status in American policymaking derived more directly, however, from David Bruce's personal admiration, which approached hero-worship, for Monnet ${ }^{23}$. Bruce headed the Marshall Plan mission in Paris, and both then and later as ambassador to France, Assistant Secretary of State, special representative on integration issues, and ambassador to the

${ }^{18}$ Kaspi, op.cit., passim.

${ }^{19}$ Irwin Wall, Jean Monnet, the United States and the French Economic Plan, in: Douglas Brinkley (ed.), Jean Monnet and the Path to European Unity (New York 1991) 86-113.

20 Ibid.

21 Jean-Pierre Rioux, The Fourth Republic, 1944-1958 (Cambridge/UK 1987) 175.

22 Ibid.

${ }^{23}$ John Gillingham, David Bruce (unpublished manuscript, "Monnet and the Americans", Franklin Delano Roosevelt Library, Hyde Park, NY 10 October 1991). 
Federal Republic, would serve as a conduit for Monnet's ideas to the State Department and White House. He was also one of the main focal points around which young "Monnetists" crystalized in the American foreign policy establishment. Bruce's first great service to Monnet was to help France secure a disproportionate amount of assistance under the European Recovery Program. He also saw to it that, in implementing the Marshall Plan, the Economic Cooperation Administration and the State Department turned to the man he referred to as The Inspirer.

The Marshall Plan was like a flying saucer. No one knew quite what it was, where it had come from, when and where it would go, or what might be left after its departure, though it evidently had something to do with trade liberalization, economic cooperation, and European initiative. The Paris conference, which opened in July 1947, was to be the forum in which the recipient nations were to establish priorities, agree upon ground rules, and devise the mechanisms needed to make the aid program work. Robert Marjolin, Monnet's deputy at the Plan and French delegate to the conference, soon became its "unofficial secretary general", in part because "most of the national governments represented did not have a national plan and some not even an overall picture of the national economy". Marjolin directed the compilation of national technical reports containing fouryear sectoral development programs with forecasts for output, consumption, exports, and import requirements. He then drafted a general report, including this data in summary form, that set four priorities: maximum investment; currency stabilization; international cooperation; and a balance of payments between donor and recipient ${ }^{24}$.

Marjolin's report was useless in aid distribution - the requirements it listed far exceeded anything that Congress might have appropriated - but otherwise bore fruit. The Paris conference mutated by turns into the Council for European Economic Cooperation and the Organization for European Economic Cooperation (OEEC). With Marjolin as director-general, OEEC became a data-gathering body, set trade rules, represented Europe vis à vis the United States, and generated an important offshoot, the European Payments Union (EPU), through which convertibility was restored in 1958. If, to the great disappointment of both the Economic Cooperation Administration and the State Department, the OEEC never developed as a center of policymaking for the Marshall Plan nations, blame was due above all to persistent British opposition to anything smacking of federalism. By default, leadership within the organization remained with the Monnetist French, to whom Washington would turn for guidance on the "integration" question $^{25}$.

It is necessary to apostrophize the word because, when ERP Administrator Paul Hoffman first used it in a speech delivered in October 1949 before the OEEC Council, no one quite knew what it meant. Hoffman intended to distinguish Mar-

${ }^{24}$ Robert Marjolin, Architect of European Unity: Memoirs, 1911-1986 (London 1989) 184190.

25 Ibid. 191-196. 
shall Plan aims from the disintegration that had plagued the interwar European economy. What he had in view for Europe was, quite simply, a customs union for the OEEC nations ${ }^{26}$. The German Question stood in the way of such a settlement. Would the ex-Reich not overwhelm its recent victims in open competition? How might the playing field be leveled politically and administratively to prevent that from happening?

The Schuman Plan provided the diplomatic answer to those questions. Its success depended on several things. It presupposed a commitment to modernization in France and an end to hegemonic aspirations in Germany. The postwar era had brought decisive change in both respects, at least at the leadership level. It also required a tradition of cooperation between national industries. One had existed since the 1920's, but needed to be revived. It rested additionally upon adroit and determined diplomacy for the difficult transition from the aftermath of war to the new conditions of peace. At this game Adenauer and Monnet were both masters ${ }^{27}$.

Yet, success of the Schuman Plan depended ultimately on the United States as guarantor. How long and under what conditions might it play that role? The Marshall Plan committed the United States to supporting European recovery for four years in order to permit withdrawal once Europe had been stabilized and an institutional framework to promote economic growth was put in place. NATO had a similar purpose from Washington's standpoint: to suppress intra-European conflict in the interest of common defense against a present Soviet threat and a possible future German danger. The United States offered its services as underwriter and subsidizer of the alliance in order to decrease - not to increase - its commitment to defend the continent. The European members of NATO for their part all recognized that if the Soviets were to be kept out and the Germans to be kept down, the Americans had, first and foremost, to be kept in ${ }^{28}$.

The outbreak of the Korean War turned NATO from an alliance into a security organization. That event resulted in a fundamental policy shift, the upshot of which, worked out over the next eighteen months, had several consequences: the stationing of American troops in Europe to provide the backbone of defense against Soviet invasion; the creation of an integrated chain of command and a joint strategy; the commitment of NATO members to force levels that required common budgeting and other forms of economic coordination; and a promise by the United States to pay many of the bills until the nations of Europe could do so. As one of the three "Wise Men" responsible for working out force levels and costsharing in preparation for the January 1952 Lisbon Conference, at which NATO

${ }^{26} \mathrm{John}$ Gillingham, The Marshall Plan and the Origins of Neo-Liberal Europe (unpublished manuscript, "The Fiftieth Anniversary of the Marshall Plan. Retrospect and Prospect", Netherlands Institute of International Relations, 16-17 May 1997).

27 Gillingham, Coal, Steel, op.cit.

${ }^{28}$ See articles by Jan van der Harst, Irwin M. Wall, Peter Foot, and E. Timothy Smith, in: Francis $H$. Heller and John R. Gillingham (eds.), NATO: The Founding of the Atlantic Alliance and the Integration of Europe (New York 1992) 25-99. 
acquired its new organizational structure, Monnet helped "entangle" the United States in Europe's affairs ${ }^{29}$.

The Schuman Plan negotiations, which began in June 1950 and concluded the following April, took place against the broad background of the new US commitment to the defense of Europe, but at the same time increased Washington's willingness to make it. Monnet and his associates offered not only to relieve NATO of half its burden by solving the German problem, but in so doing create a transRhenish alliance that would provide the nucleus of a wider European organization, including in the first instance the Benelux nations and Italy, that could become the core of a future union. Thus the term integration, initially synonymous with a customs union, took on a new meaning, a Franco-German federalization of Europe by economic means. The prospect of European political unification appealed immensely to Washington, as a fulfillment of the aims of the Marshall Plan and, if somehow a military component could be added, of NATO as well.

The proposals that the French tabled at the coal-steel discussions in Paris offered the Germans not present but future equality in a European heavy-industry pool upon fulfillment of a specific set of conditions. A new High Authority would then take over many of the regulatory powers then still being exercised by the occupation governments in the West German economy. Those were considerable. The International Authority for the Ruhr determined coal export volumes. The Level-of-Industry Agreement set allowable steel outputs. Military Security Boards vetted industrial investment. Law 27 required decartelization and deconcentration. Factory dismantling, though suspended, could be resumed ${ }^{30}$.

These occupation laws, rules, edicts, and decrees had to be scrapped for any return to business as usual. This, of course, was why Ruhr industry entered the Schuman Plan negotiations. Their success hinged on German assent to the transfer of powers from the Allied High Commissioners to the High Authority, above all those in the field of decartelization and deconcentration. Existing rules mandated the break-up of agreements in restraint of trade, a ban on "predatory pricing" and various subsidies, as well as restrictions on new investment. The subtext was that the High Authority would permit operations to resume in the Ruhr up to the point that the industry of the district threatened to become overly powerful131.

Secretary of State Dean Acheson's surprise announcement at the September 1950 New York foreign ministers' conference that the United States planned to proceed with the armament of four German divisions nearly sank the Schuman Plan negotiations. It did not, however, catch Monnet unprepared. He knew that the war in Korea would result in a build-up of forces in Europe and understood clearly that the defense of the West would have to take place at the German border and include German troops. He was also painfully aware that a French public,

${ }^{29}$ Charles S. Maier, Finance and Defense: Implications of Military Integration, in: Heller and Gillingham, op.cit., 335-353.

30 Gillingham, Coal, Steel, op.cit., 189-217.

31 Ibid. 
horrified at the prospect that les Boches might be put back into uniform, needed reassurances before any progress could be made toward the construction of the heavy-industry pool ${ }^{32}$.

Within a few weeks of Acheson's bombshell, Monnet had planted a couple of landmines of his own. And for the first emplacement the United States - in this instance represented by Ambassador Bruce in Paris and another close Monnet associate, US High Commissioner in Germany John J. McCloy - provided a shovel. The device took the form of highly restrictive, even punitive, bans on any form of marketplace collusion. Members of McCloy's staff actually helped write the decartelization and deconcentration articles of the draft treaty. Their obvious target was the smokestack barons. The riposte of the Schlotbarone was an assiduous attempt to renew cartel friendships in western Europe. Having failed to get the objectionable provisions repealed, they threatened to bolt the Paris conference. McCloy thereupon warned that he would undertake decartelization under the authority of his office (Law 27). With the imminent ruin of his "confidence building" policy in view, Adenauer forced the Ruhr leadership to knuckle under in January 1951. The negotiations were saved, and the Treaty of Paris concluded in April. The only hope for German heavy industry was that the regulatory regime of the coal-steel pool would prove unworkable ${ }^{33}$.

The proposal for a European Army, the Pleven Plan of 15 October 1950, was the second of Monnet's earth-shaking detonations. The idea had been in circulation at the Quai d'Orsay for quite some time, its appeal being mainly logistical and financial. If central provisioning were introduced for a Euro-force, could one not count on cost savings? And if in the same common military organization France monopolized the production of advanced weaponry, would not German hands be tied ${ }^{34}$ ? It was a stroke of luck that René Pleven, who had worked for Monnet during the war, was the prime minister of the day. It took Monnet only a telephone call to convince the younger man that, to rescue the Schuman Plan, France would have to propose a future European fighting force integrated down to the smallest feasible operational unit ${ }^{35}$.

The Euro-army made no military sense, but so what? Its purposes were eminently political. Eisenhower, then Supreme Allied Commander Europe, like most generals originally ridiculed the Pleven proposal, but became a convert in July 1951, when Monnet convinced him of what was at stake. Would not the integrated army give a new impetus to unification, tie Germany to the West, and prepare the way for US disengagement? Monnet did a remarkable sales job on Ike, who upon taking office as president in 1953 made the proposed force, now called the Euro-

32 Ibid. 266-283.

33 Ibid.

34 Philip Vial, Réarmement allemand, réarmement français et aide américaine. Monnet et le tournant de l'automne 1950 (unpublished manuscript, “Jean Monnet, L'Europe et les chemins de la paix").

35 Ibid. 
pean Defense Community (EDC), a top priority and even established a special mission under Bruce to lobby for it from Paris ${ }^{36}$.

Ike overlooked a number of glaring weaknesses in Monnet's presentation. The treaty for the Coal and Steel Community, with which it was to merge, had not yet been ratified; the ECSC would not open its doors until summer 1952, and, moreover, would never function properly. In reality, dirigisme generated much heat but little fire. In November 1954, Monnet resigned as president of the High Authority, frustrated by the lack of accomplishment. As for the EDC, it was sorely deficient as a platform for future integration; not least of all because it could not have operated independently, but only subject to NATO command and strategy. EDC embodied other drawbacks of a political nature. Common provisioning required common budgeting and a directorate of European civil servants to set national contributions. Hence the proposal linked the integration of Europe to an antiparliamentary set of rules that would have fostered a European version of the military-industrial complex whose development in the United States so troubled the American president.

The EDC lacked popular and parliamentary support everywhere in Europe and was at best accepted grudgingly as a means of appeasing the Americans. Adenauer, though an official enthusiast, regarded EDC as a distinctly less desirable alternative to full German membership in NATO. Endorsement of the Euro-army was, however, the price he had to pay for the Generalvertrag of May 1952, which pending ratification of the EDC treaty, was to have ended the occupation. In August 1954, however, the French Assembly rejected the EDC. Within six months the preferred NATO solution had come to pass, and the Allied High Commission found itself packing its bags. Adenauer had won a windfall victory ${ }^{37}$.

Who paid for the failure of the EDC? Secretary of State Dulles, an almost slavish admirer of the French prestidigitator, went into a deep funk after hearing of the Assembly's rejection of the treaty, and Bruce confided to his diary a personal fear that the Communists had won the biggest battle in the Cold War. Both men were, of course, wrong about the cost, and not only because a "NATO solution" was readily available. They were also wrong because the European public would have to had to pay a high political price to pay for the EDC. Still others, namely those "drüben", may actually have done so. New material from Soviet and bloc archives is now disclosing the full extent of the problems facing the Kremlin in the year after Stalin's death, and in particular the gravity of the crisis that broke into the open with the Berlin uprising ${ }^{38}$. Could the Eisenhower administration's preoccupation with the EDC have caused it to miss an opportunity to end the Cold War?

36 Gillingham, American Monnetism, op.cit., 28.

37 Hans-Peter Schwarz, Konrad Adenauer: A German Politician and Statesman in a Period of War, Revolution, and Reconstruction v. 1 (Providence 1991) 664-689.

38 Vojtech Mastny, The Cold War and Soviet Insecurity: The Stalin Years (New York 1996) $171-190$. 
The EDC would have been a wrong turn in the history of integration. Events were moving in a different direction, and away from Monnet-style dirigisme. The coal-steel pool provided a reentry vehicle for Germany into Europe, and an indispensable beginning to a new era of European cooperation. What reconciled the rest of Germany to Europe, however, was not a structure of supranational institutions but the experience of prosperity. The Federal Republic was the engine that generated it. The ECSC in fact contributed little to the Great Boom of the 1950's and had at best a secondary impact on the West European coal and steel industry, which was at any rate already in decline. The High Authority suffered a premature hardening of the arteries. In spite of continued American financial and diplomatic support, the ECSC was in fact soon all but forgotten, except in West Germany, by the European public ${ }^{39}$.

The history that led in 1958 to the creation of the European Economic Community began with the organization of the Marshall Plan commercial and financial institutions and proceeded from there to Minister of Economics Ludwig Erhard's liberalization of the West German economy. It both triggered an export boom and created rapidly expanding import markets for Germany's neighbors. Within the OEEC, import quotas largely disappeared, and tariffs dropped substantially in the early 1950's. By the middle of the decade the Federal Republic was running large payment surpluses, and the Deutschemark had become de facto convertible ${ }^{40}$. During negotiations for the "relaunching of Europe", which commenced less than a year after the EDC debacle, five of the six ECSC members, France being the exception, plumped for a customs union as an approach to advancing integration; the French too would come around when offered satisfactory transitional arrangements. Monnet's idea of advancing the process by creating a common atomic-energy agency, EURATOM, as a sectoral parallel to the ECSC, gained only State Department support. The stillbirth of EURATOM was not in truth an American policy failure, though Monnetists in the State Department who had lobbied for it regarded it as such ${ }^{41}$. The Marshall Plan aimed at liberalization, not sectoral integration, and restoration; in forming the Common Market, the nations of the Six had done things a European, but at the same time the American, way.

The Kennedy administration forgot the underlying idea of both the Marshall Plan and NATO - that the United States should engage with, in order to disengage from, Europe. It did not recognize that a healthy Europe needed guidance far less than a sick one. In a the Fourth of July 1962 address delivered in Philadelphia's Independence Hall, the president presented his Grand Design to the public. It called for a new partnership between the United States and a United Europe, but hardly an equal one. Though traditional in its emphasis on trade liberalization and European federation, it represented a sharp break with the policies of both Tru-

39 Spierenburg and Poidevin, op.cit.

40 B. R. Mitchell, European Historical Statistics, 1750-1970 (New York 1975).

41 Varsori, op.cit. 
man and Eisenhower. Kennedy's plans aimed at permanent European military dependence on the United States ${ }^{42}$.

If Monnet inspired the Fourth of July speech, George Ball, Undersecretary of State for Europe, was the man responsible for translating its ambitions into policy. Ball had served as a paid political advisor to Monnet since the 1940's and remained an intimate friend. Secretary of State Rusk, increasingly preoccupied with events in southeast Asia, gave Ball a free hand in Europe. He soon installed a cabal of the Inspirateur's disciples, Theologians as they were called, in his wing of the house, and they ran State integration policy ${ }^{43}$.

Ball meant to force the UK to enter the EEC, for its own good and even against its wishes, thereby bringing its partners in the European Free Trade Association (EFTA) along with it. The problem of Britain's place in the world would then be settled, the EEC strengthened as the nucleus of a federal Europe, and the customs union expanded. Ball also hoped to initiate a round of worldwide tariff reductions. To that end, Congress passed the administration-sponsored Trade Expansion Act (TEA) in 1962. Armed with its authority, the president could cut tariffs by category rather than merely by item in cases where the United States and the EEC controlled 80 percent of world trade, a condition that would only obtain, however, if the UK joined the Common Market. Finally, to secure the new transAtlantic partnership, the United States offered to sponsor a Multinational Force, a Euro-Navy armed with American missiles ${ }^{44}$.

These arrangements went for the grand slam: a Monnetist Europe locked into transatlantic alliance with the United States by nuclear partnership. Actually, they were more like a grand sham. To get at the truth about MLF, one had to penetrate layers of classified information, strategic bafflegab, and official misrepresentation, but at bottom it was the military equivalent of a Potemkin village. The Euro-Navy could fly its own flag, but its missiles were to remain under American control. It is hardly surprising that neither Britain nor France were enthusiastic about having to give up their homemade, handcrafted atomic war toys in order to join MLF. Persuasion having met with little success, the administration decided to pull the rug out from under the British by cancelling the US-built Skybolt air-to-ground missile, without which the UK lacked a future delivery system ${ }^{45}$.

Faced at the December 1962 Nassau meeting with a policy disaster that might well have brought down his government, Prime Minister Macmillan scraped out a compromise. To offset the loss of Skybolt, the United States would authorize the British to build submarines of American design equipped to fire Polaris missiles. Here was the appearance of victory, but none of the substance; although the

${ }^{42}$ Jobn Gillingham, Foreign Policy as Theology: The Failure of Kennedy's Grand Design (unpublished manuscript, October 1994).

${ }^{43}$ Pascaline Winand, The European Challenge: Eisenhower, Kennedy, and the United States of Europe (New York 1994).

${ }_{44}$ George Ball, The Discipline of Power: Essentials of a Modern World Structure (New York 1968).

45 George Ball, The Past Has Another Pattern (New York 1982) $162 \mathrm{f}$. 
matter was kept hush-hush, the weapons remained under American control. The purported special relationship of the Anglo-Saxons, so seemingly manifest in the Polaris deal, gave de Gaulle a welcome pretext to torpedo Britain's request to enter the EEC. Therewith TEA became a dead letter; the Grand Alliance went to the back burner; and the State Department Theologians returned to their parishes. Ball hung on, a peripheral figure, for another five years ${ }^{46}$. Viet Nam did not kill State Department Monnetism. It died of inanition.

Monnet became the Father of Europe because he was the man most responsible for engaging the United States in the effort to build it. The need for an American presence, apparent in 1918, was after 1945 imperious. An adequate explanation of "entanglement" must include two histories that fall beyond the scope of this essay - the political learning process that occurred in the United States after 1945 as well as the Cold War that contributed to it. It was by no means a foregone conclusion that the United States would direct the reorganization of Europe after World War II. Nor was it certain that an American administration would make the necessary compromises. Much distance had to be crossed to get from Roosevelt's lofty globalism to support for what initially struck Dean Acheson as being a scheme for the damndest supercartel ever invented by man. The Schuman Plan announcement nonetheless broke the Franco-German impasse. The negotiations resulting from it provided a critical first step to reconciliation. Monnet's claim to have inspired the ECSC and engineered its realization is almost universally recognized; less so, however, the extent to which that accomplishment rested on American support. Probably only Monnet could have won it. In the absence of the ECSC the reconciliation of France and Germany surely would have taken longer and NATO would have been weaker. Monnet helped lay the foundation of the new Europe, but also its cornerstone, the Atlantic Alliance.

46 Ibid. 317-403. 
